\title{
HAS THE WHARTON BASIN'S HEAT FLOW BEEN PERTURBED BY THE FORMATION OF A DIFFUSE PLATE BOUNDARY IN THE INDIAN OCEAN?
}

\author{
Carol A. Stein, ${ }^{1}$ Michael A. Hobart, ${ }^{2}$ Dallas H. Abbott, ${ }^{2}$ \\ ${ }^{1}$ Department of Geological Sciences, University of Illinois at Chicago \\ ${ }^{2}$ Lamont-Doherty Geological Observatory, Columbia University
}

\begin{abstract}
The Central Indian Ocean region has heat flow higher than expected for its lithospheric age. This heat flow anomaly is thought to be associated with deformation of sediment and crust and high seismicity. To better constrain the nature of this deformation, we examine the spatial variation of the heat flow. Previous work suggested high heat flux also in the Wharton Basin to the east, which shows less seismicity and deformation. Using new values for lithosphenc age from reinterpretation of the magnetic anomalies, we have reexamined the heat flow and found it no higher than expected, in contrast to the Central Indian Basin. This spatial distribution of heat flow highs and expected values is consistent with the pattern of seismicity and deformation and the predictions of the recent diffuse plate boundary model [Wiens et al., 1985] for the region.
\end{abstract}

\section{Introduction}

The Central Indian Basin, between the Ninetyeast and Chagos-Laccadive Ridges, has long been known as a seismically active region [Gutenberg and Richter, 1954; Sykes, 1970; Stein and Okal, 1978; Wiens, 1985; Bergman and Solomon, 1985] (Figure 1). In this area, sediments and acoustic basement are sometimes deformed into longwavelength (100-300 km) "undulations", often with closelyspaced (1-3 km) faults superimposed and up to $3 \mathrm{~km}$ of relief. This deformation is also associated with large (30-80 mgal) free-air gravity anomalies [Weissel et al., 1980; Geller et al., 1983], and east-west trending geoid anomalies with amplitudes up to $-2 \mathrm{~m}$ [McAdoo and Sandwell, 1985]. In addition, the heat flow is higher than expected for the lithospheric age [Anderson et al., 1977; Weissel et al., 1980]. The seismicity, high heat flow and deformation are thought to be associated with a diffuse plate boundary separating distinct Indian and Australian plates [Wiens et al., 1985].

Whether this deformation extends eastward to the Wharton Basin is unclear. The Wharton Basin is less seismically active than the Central Indian Basin (Figure 1), and the deformation and faulting are less spectacular [Geller et al., 1983]. On the other hand, the SW-NE trending geoid anomalies are about the same magnitude as west of the Ninetyeast Ridge [Haxby, 1987]. Anderson et al. [1977] calculated that the heat flow in the Wharton Basin is about 8 $\mathrm{mWm}^{-2}$ greater than predicted for its age.

In this paper, we examine spatial variation of the heat

Copyright 1988 by the American Geophysical Union.

Paper number 7L7290.

0094-8276/88/007L-7290\$03.00

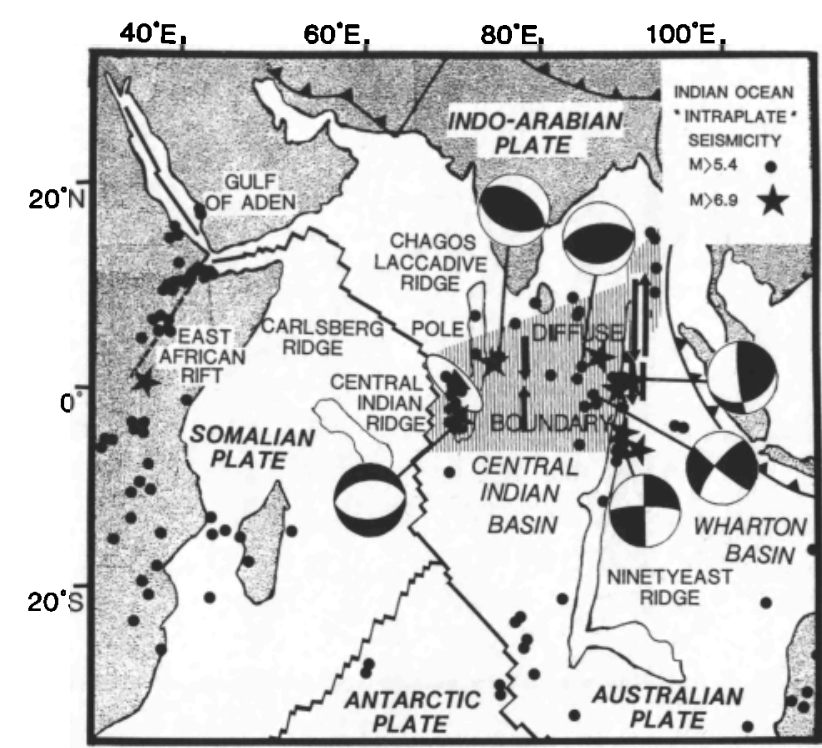

Fig. 1. Plate geometry and "intraplate" seismicity (19121983) in the Indian Ocean. The epicenters plotted indicate the proposed diffuse plate boundary, and remaining intraplate deformation. The Wharton Basin has less seismicity than the Central Indian Basin and the Ninetyeast Ridge and Chagos-Laccadive Ridge. Solid triangle and ellipse indicate the location of the Euler pole and $95 \%$ confidence limits. Arrows show expected motion in the diffuse plate boundary. After Wiens et al. [1985].

flow within the Wharton and Central Indian Basins. For the Wharton Basin, we use new magnetic anomaly identifications [Liu et al., 1983], which imply generally younger lithospheric ages for the heat flow measurement sites than the earlier model of Sclater and Fisher [1974]. We find that heat flow in the Wharton Basin, in contrast to the Central Indian Basin, is no higher than expected. This difference is in accord with the predictions of the diffuse plate boundary model, since that boundary appears not to extend east of the Ninetyeast Ridge.

\section{Data}

We excluded all measurements on hot spot tracks, on oceanic plateaus with possible continental fragments, in areas of insufficient sediment cover [Anderson and Hobart, 1976] and from stations with dubious experimental quality (see Figure 2). We have reanalyzed the Lamont-Doherty Geological Observatory heat flow data. Magnetic anomaly 


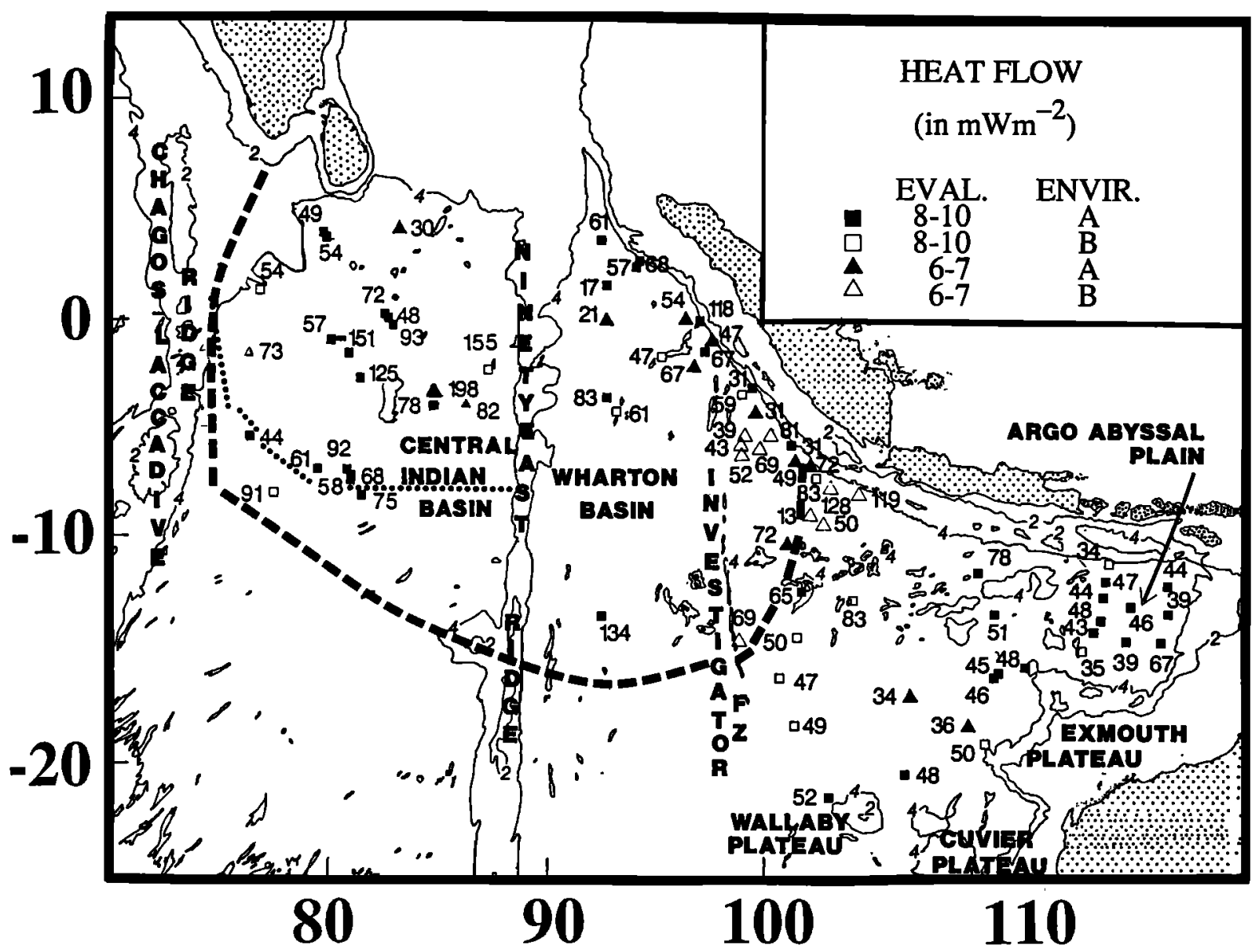

Fig. 2. Location and value of heat flow measurements [Anderson et al., 1977; Geller et al., 1983] used for this study. Eval- Evaluation of heat flow measurement based on quality [Langseth and Taylor, 1967]. Envir- Sedimentary environment, well sedimented regions in A and B category [Sclater et al., 1976]. Dotted line- southern limit of Bengal Fan. Dashed line- southern limit of Central Indian and west Wharton Basins' study area.

identifications are from Liu et al. [1983] (western portion of the Wharton Basin), Sclater and Fisher [1974] (Central Indian Basin), and Fullerton and Sager [1987] (east of $105^{\circ} \mathrm{E}$ and north of the Wallaby Plateau). The time scale is from Harland et al. [1982].

We grouped the heat flow measurements (Figure 2) into four regions, the Central Indian Basin (CIB), east and west Wharton Basins divided about $102^{\circ} \mathrm{E}$, and the Argo Abyssal Plain, between Java-Sunda Trench, Australia and about $113^{\circ} \mathrm{E}$. In addition, we isolated those of the CIB measurements on the Bengal deep-sea sediment fan. We calculated the difference between the observed heat flow and that predicted theoretically at the appropriate age [Parsons and Sclater, 1977] for individual measurements, and then found the regional mean differences and their standard deviation (Table 1). For the Central Indian Basin the mean difference is $27 \pm 31 \mathrm{mWm}^{-2}$. Sixty-eight percent of the heat flow values exceed or equal the theoretical values. The Bengal Fan, with the most sediment/acoustic basement deformation, has a mean difference of $30 \pm 30 \mathrm{mWm}^{-2}$. The heat flow from the Bengal Fan region is underestimated, due to thermal blanketing effects from rapid sedimentation [Langseth et al., 1980]. Although individual corrections for sedimenta- tion rate effects are as high as $+28 \%$, sedimentation is much slower on topographic highs. Thus, the average increase in the heat flow anomaly is only $1-5 \mathrm{mWm}^{-2}$, because the sites on local topographic highs have much slower sedimentation.

In contrast, only $31 \%$ of the heat flow values in the west Wharton Basin exceed or equal the theoretical values. The mean difference is $-4 \pm 26 \mathrm{mWm}^{-2}$. The higher values in the

Table 1-Regional Heat Flow

\begin{tabular}{lcrccr}
\hline Region & N & $\overline{\text { age }}$ & $\overline{\mathbf{Q}}$ & $\overline{\mathrm{x}}$ & $\sigma$ \\
\hline Bengal Fan & 19 & 75 & 85 & 30 & 30 \\
Central Indian & 22 & 73 & 82 & 27 & 31 \\
e. Wharton & 21 & 99 & 59 & 10 & 22 \\
w. Wharton & 26 & 59 & 59 & -4 & 26 \\
Argo Abyssal & 11 & 155 & 44 & 5 & 8 \\
\hline
\end{tabular}

$\mathrm{N}=$ number of heat flow measurements; $\overline{\text { age }}=$ average age (Ma) of measurements; $\bar{Q}=$ mean measured heat flow, $\mathrm{mWm}^{-2} ; \overline{\mathrm{x}}=\mathrm{N}^{-1} \Sigma\left(\mathrm{Q}_{\text {measured }}-\mathrm{Q}_{\text {theoretical }}\right) ; \sigma=$ standard deviation of $\bar{x}$ 
west Wharton Basin are scattered randomly, often next to much lower values, but the CIB contains a large region with consistently high values. The east Wharton Basin is substantially older than the west part of the basin and has a mean difference of $10 \pm 22 \mathrm{mWm}^{-2}$. The heat flow for the Argo Abyssal Plain is what would be expected for its age.
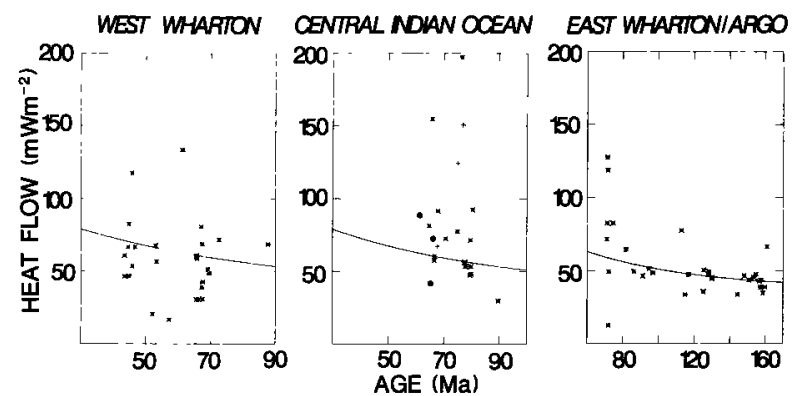

Fig. 3. Heat flow vs. age. Solid curve- theoretical heat flow vs. age [Parsons and Sclater, 1977]. Average heat flow in the Central Indian Ocean is significantly greater than theoretically expected, whereas heat flow in the west Wharton Basin is approximately that expected. For the Central Indian Basin data, dots indicate sites not on the Bengal Fan, and crosses are an average of nearby measurements [Geller et al., 1983].

Heat flow for all regions shows the characteristic scatter (Figure 3) with standard deviations comparable to those for this age range in Sclater et al.'s [1980] global compilation. To test whether the high heat flux results from a few extreme $\left(>100 \mathrm{mWm}^{-2}\right.$ ) values reflecting local perturbations unrelated to the overall thermal structure, we recomputed the mean differences without these values and found $10 \pm 13$ $\mathrm{mWm}^{-2}$ for the CIB, $10 \pm 13 \mathrm{mWm}^{-2}$ for the Bengal Fan, and $-9 \pm 16 \mathrm{mWm}^{-2}$ for the west Wharton Basin. Thus, despite the noisy data, we conclude that the Central Indian Basin heat flow is significantly greater than expected and that there is no high heat flow anomaly in the western Wharton Basin.

\section{Discussion}

Given that the anomalously high heat flow is thought to be of tectonic origin, we examined its spatial distribution and possible tectonic correlation. For these purposes, we used observed seismicity, focal mechanisms, and deformation and the predictions of plate kinematic and stress models. The high heat flow in the Central Indian Basin occurs in a region with more sediment deformation and higher seismicity than in the Wharton Basin. This area's boundaries can be defined by the change in focal mechanisms from thrust to normal fault near the Chagos-Laccadive Ridge (Figure 1), the strike-slip focal mechanisms along the Ninetyeast Ridge, and the rapid decrease in seismicity south of about $16^{\circ} \mathrm{S}$. The western Wharton Basin has less seismicity than the CIB, but more than the eastern Wharton Basin. East of about $102^{\circ} \mathrm{E}$ the seismicity sharply decreases. This distribution of deformation and seismicity can be described by the presence of a recently formed diffuse plate boundary (Figure 1), extending from the Central Indian Ridge to the Ninetyeast Ridge, which separates the Indo-Arabian and Australian plates [Wiens et al., 1985]. This geometry fits relative motion data along the Central Indian and Carlsberg Ridges better than the previously used single plate geometry, and predicts the observed focal mechanisms and deformation. Thus high heat flow, if produced by the diffuse boundary tectonics, should occur in the CIB but not the Wharton Basin.

It is interesting to note that the distribution of heat flow, deformation, and seismicity is also consistent with the regional stress patterns predicted by mechanical models [Cloetingh and Wortel, 1985] for the conventionally-defined Indo-Australian plate. Cloetingh and Wortel [1985] calculated compressive stresses for a region in the Central Indian and west Wharton Basins, whose boundaries are indicated in Figure 2 (dashed line). They also found extentional stresses to the south of the compressional stress region, to the west near the Chagos-Laccadive, Central and Carlsberg Ridges, and east into the east Wharton Basin and Argo Abyssal Plain. Although the magnitudes of the stresses depend on the assumed forces at the convergent plate boundaries [Richardson, 1987], the compressive stresses predicted throughout the Bengal Fan, Ninetyeast Ridge regions and the west Wharton Basin are comparable to those [Zuber, 1987; McAdoo and Sandwell, 1985] required to produce longwavelength deformation in the Central Indian Basin.

The absence of a heat flow anomaly and the low seismicity suggest that the west Wharton Basin is presently deforming much less than the CIB. The gravity and sediment data, however, indicate past deformation. These observations may reflect the timing of the formation of the new plate boundary, presumably associated with the onset of sediment deformation $7 \mathrm{Ma}$ [Geller et al., 1983; Shipboard Scientific Party, ODP Leg 116, 1987]. Subsequently, intraplate strain, originally distributed in both the Wharton and Central Indian Basins, may have concentrated on the Ninetyeast Ridge and in the Bengal Fan.

The mechanism by which additional heat is added to the lithosphere in the Central Indian Basin is unknown but is presumably associated with the deformation. If the lower lithosphere had been reheated to produce the observed heat flow anomaly, the required increase in temperatures should result in about $1 \mathrm{~km}$ of basement uplift [Crough, 1978]. No such uplift is present [Stein, 1984]. Moreover, for conductive heat transfer, only a shallow $(<20 \mathrm{~km})$ heat source could cause a surface heat flow anomaly within the 7 Ma since the onset of deformation. More rapid heat transport could occur by water flow; some of the high heat flow measurements in the CIB are associated with regions of upward water convection [Geller et al., 1983]. Deformation and faulting may have resulted in increased dewatering of the thick Bengal Fan sediments but no clear correlation exists between the seismicity and the high heat flow sites. Heat flow sites with water flow occur both in deformed uplifted areas that have received less than $5 \mathrm{~m}$ of sediment since uppermost Miocene time and depressed areas that have received much more sediments [Geller et al., 1983]. Depending on the sediment properties, dewatering might occur over several million years. However, it is unlikely that this mechanism can account for the $27 \mathrm{mWm}^{-2}$ additional heat flow. Also, one would expect sites where dewatering had already stopped and the heat flux 
is significantly less than expected, but there is no evidence of this phenomena.

Acknowledgements. We thank Fullerton and Sager for providing copies of their magnetic anomaly identifications for the easternmost Indian Ocean. This research was supported primarily by a Summer Research Fellowship provided by the Petroleum Research Fund, administered by the American Chemical Society. Funding for computation was from a grant from the University of Illinois at Chicago's Research Board. Data collection was mainly funded by LamontDoherty Geological Observatory. W. Haxby and three anonymous reviewers contributed useful suggestions. Lamont-Doherty Geological Observatory Contribution number 4280.

\section{References}

Anderson, R.N., M. G. Langseth, and J. G. Sclater, The mechanisms of heat transfer through the floor of the Indian Ocean, J. Geophys. Res., 82, 3391-3409, 1977.

Anderson, R. N., and M. A. Hobart, The relation between heat flow, sediment thickness, and age in the eastern Pacific, J. Geophys. Res., 81, 2968-2989, 1976.

Bergman, E.A., and Solomon, S.C., Earthquake source mechanisms from body-waveform inversion and intraplate tectonics in the northern Indian Ocean, Phys. Earth Planet. Int., 40, 1-23, 1985.

Cloetingh, S. and R. Wortel, Regional stress field of the Indian plate, Geophys. Res., Lett., 12, 77-80, 1985.

Crough, S. T., Thermal origin of mid-plate hot-spot swells, Geophys. J. R. astron. Soc., 55, 451-469, 1978.

Fullerton, L. G. and W. W. Sager, Late Jurassic-Early Cretaceous tectonic evolution of the eastern Indian Ocean adjacent to Northwest Australia, EOS, 68, 424, 1987.

Geller, C. A., J. K. Weissel, and R. N. Anderson, Heat transfer and intraplate deformation in the central Indian Ocean, J. Geophys. Res., 88, 1018-1032, 1983.

Gutenberg, B., and C.F. Richter, Seismicity of the Earth, Princeton University Press, Princeton, N.Y., 1954.

Harland, W. B., A. V. Cox, P. G. Llewellyn, C. A. G. Pickton, A. G. Smith, and R. Walters, A Geologic Time Scale, Cambridge Univ. Press, Cambridge, MA, 1982.

Haxby, W., Gravity Field of the World's Oceans, National Geophysical Data Center, 1987.

Langseth, M. G., M. A. Hobart, and K. Horai, Heat flow in the Bering Sea, J. Geophys. Res., 85, 3740-3750, 1980.

Langseth, M. G. and P. T. Taylor, Heat flow in the Indian Ocean, J. Geophys. Res., 72, 6249-6260, 1967.

Liu, C. S., J. R. Curray, and J. M. McDonald, New constraints on the tectonic evolution of the eastem Indian Ocean, Earth Planet Sci. Lett, 65, 331-342, 1983.

McAdoo, D. C., and D. T. Sandwell, Folding of oceanic lithosphere, J. Geophys. Res., 90, 8563-8569, 1985.
Parsons, B., and J. G. Sclater, An analysis of the variation of ocean floor bathymetry and heat flow with age, J. Geophys. Res., 82, 803-827, 1977.

Richardson, R. M., Modeling the tectonics of the IndoAustralian plate, EOS, 68, 1466, 1987.

Sclater, J. G., J. Crowe, and R. N. Anderson, On the reliability of oceanic heat averages, J. Geophys. Res., 81, 29973006, 1976.

Sclater, J. G., and R. L. Fisher, The evolution of the east central Indian Ocean, with emphasis on the tectonic setting of the Ninetyeast Ridge, Geol. Soc. Am. Bull., 85, 683-702, 1974.

Sclater, J. G., C. Jaupert, and D. Galson, The heat flow though oceanic and continental crust and the heat loss of the earth, Rev. Geophys. Space Phys., 18, 269-311, 1980.

Shipboard Scientific Party, Leg 116, Intraplate deformation and Himalayan uplift, ODP Leg 116, Eos, 68, 1444, 1987.

Stein, C. A., Part I- Heat transfer, seismicity, and intraplate deformation in the Central Indian Ocean; Part II-The transition between the Sheba Ridge and the Owen Basin: Rifting of old oceanic lithosphere, $P h . D$. thesis, Columbia University, New York, pp. 151, 1984.

Stein, S. and Okal, E. A., Seismicity and tectonics of the Ninetyeast Ridge area: evidence for internal deformation of the Indian Plate, J. Geophys. Res., 83, 2233-2246, 1978.

Sykes, L. R., Seismicity of the Indian Ocean and a possible nascent island arc between Ceylon and Australia, J. Geophys. Res., 75, 5041-5055, 1970.

Weissel, J. K., R. N. Anderson, and Geller, C. A. Deformation of the Indo-Australian plate, Nature, 287, 284-291, 1980.

Wiens, D. A., Historical seismicity near Chagos: A complex deformation zone in the equatorial Indian Ocean, Earth Planet. Sci. Lett., 76, 350-360, 1986.

Wiens, D. A., C. DeMets, R. G. Gordon, S. Stein, D. Argus, J. F. Engeln, P. Lundgren, D. Quible, C. Stein, S. Weinstein, and D. F. Woods, A diffuse plate boundary model for Indian Ocean tectonics, Geophys. Res. Lett., 12, 429432, 1985.

Zuber, M. T., Compression of oceanic lithosphere: An analysis of Intraplate deformation in the Central Indian Basin, J. Geophys. Res., 92, 4817-4825, 1987.

C.A. Stein, Department of Geological Sciences, University of Illinois at Chicago, Chicago, IL 60680.

M.A. Hobart, D.H. Abbott, Lamont-Doherty Geological Observatory, Palisades, New York 10964.

(Received December 29, 1987;

Revised March 28, 1988;

Accepted March 28, 1988) 